\title{
PENGARUH IKLAN DAN CITRA MEREK TERHADAP KEPUTUSAN PEMBELIAN KARTU SIMPATI DI KOTA JAMBI
}

\author{
Risma Amelia Irani
}

Jurusan Manajemen Fakultas Ekonomi dan Bisnis

\begin{abstract}
Advertising is to influence purchases. This research aims to analyze the influence of advertising and brand image of card simpati, either partially or simultaneous. The methods used in this research is quantitative with the survey. The number of samples is 97 respondents. Methods of analysis used was multiple linear regression. Advertising and brand image gives a strong influence of Simpati card purchases in the city of Jambi. The test results of the analysis that has been done, on the test simultaneously replied that the advertising and brand image simultaneously positive and signifivant effect against the purchasing decision. Then in partially test, two variables in this study partially equally influence purchasing decisions.
\end{abstract}

Keywords: Advertising, brand image, purchase decisions.

\section{PENDAHULUAN}

Kemunculan Handphone/ponsel menggusur penggunaan media surat ataupun telepon rumah dari tengah-tengah masyarakat. Hal ini dikarenakan setiap anggota masyarakat membutuhkan telekomunikasi untuk melakukan berbagai hal dalam kegiatan sehari-hari. Semua operator bersaing untuk mendapatkan pelanggan baru disertai mempertahankan pelanggan lama dalam meningkatkan keputusan pembelian produk yang ditawarkan oleh masing-masing operator telekomunikasi. Setiap perusahaan tentunya ingin mencapai laba yang maksimal. Shimp (2014) mengatakan bahwa Iklan yang efektif merupakan penghubung pembuat produk dengan target pasar, sehingga iklan ini dipandang sebagai informasi yang dibutuhkan dan dicari oleh konsumen ketika akan mengambil keputusan untuk pembelian.

PT Telekomunikasi Seluler (Telkomsel) merupakan operator telekomunikasi seluler GSM pertama di Indonesia dengan layanan pascabayar kartu HALO yang diluncurkan pada tanggal 26 Mei 1995. Saat itu, saham Telkomsel dimiliki oleh Telkom Indonesia sebesar 65\% dan sisanya oleh Indosat. Pada tanggal 1 November 1997, Telkomsel menjadi oprator seluler prtama di Asia yang menawarkan layanan GSM prabayar. Pertumbuhan jumlah pelanggan Telkomsel di Indonesia menjadi perhatian penting bagi manajemen perusahaan agar dapat mempertahankan posisi pasar sebagai pemimpin pasar di industri jasa telekomunikasi. Namun apakah terdapat pengaruh iklan dan citra merek terhadap keputusan pembelian konsumen memerlukan pengkajian secara empiris. Terkait dengan hal tersebut maka tujuan penulisan ini adalah untuk menjelaskan dan mengetahui pengaruh iklan dan citra merek terhadap keputusan pembelian.

Meningkatnya selera konsumen dalam memilih suatu barang atau jasa sesuai dengan kebutuhan yang diinginkan menyebabkan jenis produk yang ditawarkan semakin bervariasi sehingga produsen harus menyeleksi apa yang benar-benar menjadi kebutuhan dan keinginan dari konsumen. Bervariasinya produk yang ditawarkan oleh produsen membuat proses keputusan pembelian akan semakin panjang. Keputusan pembelian yang akan dilakukan oleh konsumen seringkali berdasarkan pada beberapa faktor, salah satunya yaitu 
citra merek yang kuat. Hal ini karena dengan memiliki merek yang kuat dan dikenal luas oleh konsumen merupakan investasi jangka panjang bagi perusahaan.

Tujuan penelitian ini adalah untuk mengetahui pengaruh iklan terhadap keputusan pembelian kartu simpati, mengetahui pengaruh citra merek terhadap keputusan pembelian kartu simpati dan menganalisis pengaruh iklan dan citra merek secara simultan terhadap keputusan pembelian kartu simpati.

\section{TINJAUAN PUSTAKA \\ Pemasaran}

Pemasaran dimulai dengan konsumen, berfokus pada konsumen dan bertujuan untuk memuaskan kebutuhan dan keinginan konsumen. Organisasi pemasaran dan para pemasar harus memahami kebutuhan konsumen, kemudian menyediakan dan menawarkan produk yang dibutuhkan dengan nilai dan kualitas yang baik, harga yang layak, distribusi yang luas dan diiringi komunikasi yang baik dan efektif untuk menarik minat konsumen.

Terminologi penting yang perlu dipahami dalam marketing adalah kebutuhan (needs), keinginan (wants) permintaan (demands), produk (products), nilai (value), kepuasan (satisfaction), mutu (quality), pertukaran (exchanges), transaksi dan hubungan (transaction and relationship) dan pasar (market). Manajemen pemasaran adalah analisis, perencanaan, pelaksanaan, dan pengendalian atas program yang dirancang untuk menciptakan, membangun, dan mempertahankan pertukaran yang menguntungkan dengan pembeli sasaran dengan maksud untuk mencapai sasaran organisasi (Kotler,2002).

\section{Marketing Mix}

Salah satu strategi yang berhubungan dengan kegiatan pemasaran perusahaan adalah marketing mix strategy yang didefinisikan oleh Kotler dan Armstrong (1997) yang menyatakan bahwa "marketing mix as the set of controllable marketing variables that the firm bleads to produce the response it wants in the target market". Definisi tersebut di atas dapat dimaknai bahwa bauran pemasaran merupakan varaibel terkendali yang digabungkan untuk menghasilkan tanggapan yang diharapkan dari pemasaran. Khsusus untuk usaha jasa terdapat 7 unsur marketing mix (Marketing Mix-\&p) yakni product, price, promotion, place, participant, process, dan physical evidence.

\section{Product (Produk)}

Produk merupakan elemen penting dalam sebuah program pemasaran. Strategi produk dapat mempengaruhi strategi pemasaran lainnya. Pembelian sebuah produk bukan hanya sekedar untuk memiliki produk tersebut tetapi juga untuk memenuhi kebutuhan dan keinginan konsumen.

\section{Price (Harga)}

Menurut Monroe (2005) menyatakan bahwa harga merupakan pengorbanan ekonomis yang dilakukan pelanggan untuk memperoleh produk atau jasa. Selain itu harga salah satu faktor penting konsumen dalam mengambil keputusan untuk melakukan transaksi atau tidak (Engel, Blackwell dan Miniard, 1996).

\section{Promotion (Promosi)}

Promosi adalah kegiatan mengkomunikasikan informasi dari penjual kepada konsumen atau pihak lain dalam saluran penjualan untuk mempengaruhi sikap dan perilaku. Melalui periklanan suatu perusahaan mengarahkan komunikasi persuasif pada pembeli sasaran dan masyarakat melalui media-media yang disebut dengan media massa seperti Koran, majalah, tabloid, radio, televise dan direct mail (Baker, 2000). Media promosi yang dapat digunakan pada bisnis ini antara lain (1) Periklanan, (2) Promosi penjualan, 
(3) Publisitas dan hubungan masyarakat, dan (4) Pemasaran langsung. Penentuan media promosi yang akan digunakan didasarkan pada jenis dan bentuk produk itu sendiri.

\section{Place (Saluran Distribusi)}

Kotler (2000) menyatakan bahwa "Saluran distribusi terdiri dari seperangkat lembaga yang melakukan segala kegiatan (Fungsi) yang digunakan untuk menyalurkan produk dan status pemiliknya dari produsen ke konsumen". Dari definisi diatas dapat diartikan bahwa saluran distribusi suatu barang adalah keseluruhan kegiatan atau fungsi untuk memindahkan produk disertai dengan hak pemiliknya dari produsen ke konsumen akhir atau pemakai industri.

\section{People (Partisipan)}

Yang dimaksud partisipan disini adalah karyawan penyedia jasa layanan maupun penjualan, atau orang-orang yang terlibat secara langsung maupun tidak langsung dalam proses layanan itu sendiri, misalnya dalam jasa kecantikan diantaranya adalah para reception, dokter, dan beauty therapis.

\section{Process (Proses)}

Proses adalah kegiatan yang menunjukkan bagaimana pelayanan diberikan kepada konsumen selama melakukan pembelian barang. Pengelola usaha melalui front liner sering menawarkan berbagai macam bentuk pelayanan untuk tujuan menarik konsumen. Fasilitas jasa konsultasi gratis, pengiriman produk, credit card, card member dan fasilitas layanan yang berpengaruh pada image perusahaan.

\section{Physical Evidence (Lingkungan Fisik)}

Lingkungan fisik adalah keadaan atau kondisi yang di dalamnya juga termasuk suasana. Yang dimaksud dengan situasi ini adalah situasi dan kondisi geografi dan lingkungan institusi, dekorasi, ruangan, suara, aroma, cahaya, cuaca, pelatakan dan layout yang nampak atau lingkungan yang penting sebagai obyek stimuli (Belk, 1974).

\section{Konsep periklanan}

Kata iklan berasal dari bahasa Yunani, yang artinya lebih kurang adalah "menggiring orang pada gagasan". Adapun pengertian periklanan secara komprehensif menurut kotler (2003), periklanan adalah segala bentuk penyajian dan promosi ide, barang atau jasa secara non-personal oleh suatu sponsor tertentu yang memerlukan pembayaran. Periklanan menurut (Suhandang, 2005) adalah suatu proses komunikasi massa yang melibatkan sponsor tertentu, yakni si pemasang iklan (pengiklan), yang membayar jasa sebuah media massa atas penyiaran iklannya (M. Nasir Ibrahim, 2007).

\section{Citra Merek}

Konsumen biasanya mengembangkan kepercayaan untuk setiap merek sesuai dengan atribut produknya. Kepercayaan merek tersebut nantinya akan menjadi citra merek (Kotler, 2000). Konsumen mengasosiasikan dengan nama merek. Biel (1992) dijelaskan bahwa Citra merek sebagai asosiasi dengan nama merek, iklan, kemasan, identitas perusahaan, hubungan, dan informasi yang diberikan dalam kegiatan promosi semua bisa dalam bentuk tertentu.

\section{Perilaku Konsumen}

Menurut Kotler (2005) perilaku konsumen adalah perilaku mempelajari bagaimana individu, kelompok, dan orang-orang memilih, membeli, memakai, dan membuang barang, jasa, dan gagasan atau pengalaman dalam rangka memuaskan kebutuhan dan hasrat mereka.Proses penukaran merupakan unsur utama dari perilaku konsumen. 
Jadi, ada tiga faktor yang harus diperhatikan dalam permintaan pasar untuk produk atau jasa yaitu, orang-orang dengan kebutuhan, daya beli mereka, dan perilaku beli mereka. Pembeli dapat dibedakan atas individual atau household dan industrial costumer. Perbedaan-perbedaan nyata yang dapat dilihat antara pembeli individu dengan industri adalah :

1. Pembeli industri umumnya membeli dalam jumlah yang lebih besar dibandingkan dengan konsumen individu atau rumah tangga.

2. Motivasi membeli pada konsumen industri lebih ekonomis dan tidak emosional atau dengan kata lain konsumen industri lebih objektif dalam keputusan membeli dibanding konsumen atau rumah tangga.

3. Banyak orang atau bagian dalam organisasi yang terlibat dalam pengambilan keputusan seperti bagian R\&D, teknik, dan top eksekutif.

4. Keputusan pembelian organisasi cenderung lebih tersusun. Memahami perbedaan tersebut, dapat disimpulkan bahwa pasar konsumen adalah pasar yang terdiri dari individu-individu atau rumah tangga yang membeli produk dan jasa untuk konsumen pribadi (Kotler dan Amstrong, 1997).

\section{Keputusan Pembelian}

Pengambilan keputusan konsumen adalah proses pengintegrasian yang mengombinasikan pengetahuan untuk mengevaluasi dua atau lebih perilaku alternatif dan memilih salah satu diantaranya (Setiadi,2010). Menurut Kotler (2007) Keputusan Pembelian yaitu : beberapa tahapan yang dilakukan oleh konsumen sebelum melakukan keputusan pembelian suatu produk. Sedangkan Menurut Chapman dan Wahlers (1999) Keputusan Pembelian adalah sebagai keinginan konsumen untuk membeli suatu produk. Konsumen akan memutuskan produk yang akan dibeli berdasarkan persepsi mereka terhadap produk tersebut berkaitan dengan kemampuan produk tersebut dalam memenuhi kebutuhannya.

\section{METODE PENELITIAN \\ Pendekatan Penelitian}

Pendekatan penelitian yang digunakan dalam penelitian ini adalah penelitian survei yang bersifat kuantitatif. Menurut Zikmund (1997) metode penelitian survey adalah satu bentuk teknik penelitian di mana informasi dikumpulkan dari sejumlah sampel berupa orang, melalui pertanyaan-pertanyaan.

\section{Populasi dan Sampel}

Populasi dalam penelitian ini adalah laki-laki dan perempuan yang menggunakan kartu simpati dan pernah menggunakan kartu simpati, berdomisili di kota Jambi dan berusia 17-45 tahun.penarikan sampel dalam penelitian ini menggunakan teknik accidental sampling yaitu teknik penentuan sampel berdasarkan kebetulan. Jumlah populasi secara pasti tidak diketahui, oleh karena itu ditetapkan jumlah responden yang menjadi sampel penelitian berjumlah 97 orang melalui rumus $\mathrm{Z}$.

\section{Uji Validitas dan Reabilitas Instrumen}

Uji validitas dan reabilitas adalah suatu pengujian untuk mengetahui bagaimanakah pengaruh dari variabel independen terhadap variabel dependen secara bersama-sama. Menurut Santoso (2005) validitas merupakan ukuran sejauh mana alat ukur itu mampu mengukur apa yang diukur.

untuk pengujian validitas dan reabilitas ini digunakan SPSS 19 for windows dengan menguji : 
1. apakah nilai Corrected Item-Total Correlations lebih besar dari seharusnya maka item instrumen tersebut dinyatakan valid.

2. Apabila dari output yang dihasilkan nilai Cronbach's alpha suatu variabel lebih besar dari 0.60 maka variabel tersebut dinyatakan reliabel (andal).

\section{Metode Analisis Data}

1. Analisis Regresi

Untuk menganalisis data digunakan metode analisis regresi linear berganda. Data yang diperoleh diolah dengan menggunakan program SPSS versi 19 for windows, dan menggunakan persamaan regresi linear berganda, dengan rumus:

$$
\begin{aligned}
& \mathrm{Y}=\mathrm{a}+b_{1} x_{1}+b_{2} x_{2}+\mathrm{e} \\
& \text { Diminta : } \\
& \mathrm{Y}=\text { Keputusan Pembelian } \\
& \mathrm{a}=\text { Konstanta } \\
& b_{1}=\text { Standar Koefisien Regresi dari Iklan } \\
& b_{2}=\text { Standar Koefisien Regresi dari Citra Merek } \\
& x_{1}=\text { Iklan } \\
& x_{2}=\text { Citra Merek } \\
& \mathrm{e}=\text { Error Term's }
\end{aligned}
$$

\section{PEMBAHASAN}

Keseluruhan variabel yang digunakan untuk menjelaskan iklan, citra merek dan keputusan pembelian dan hubungan antara ketiganya setelah dilakukan pengujian dengan cronbrach alpha menunjukkan bahwa keseluruhan reliabel dengan angka sebesar 0.661, 0.852 dan 0.743 , dimana batas suatu variabel dapat dinyatakan reliabel adalah sebesar lebih besar atau sama dengan 0.6. Dengan demikian keseluruhan variabel dapat digunakan dalam pengujian lebih lanjut.

Menurut Kotler (2012) perilaku keputusan pembelian mengacu pada perilaku pembelian akhir dari konsumen, baik individual, maupun rumah tangga yang membeli barang atau jasa untuk konsumsi pribadi. Pada penelitian ini, peneliti melakukan penelitian mengenai pengaruh iklan dan citra merek terhadap keputusan pembelian kartu simpati di kota Jambi.

Berdasarkan rumusan masalah yang ada, yaitu apakah iklan dan citra merek berpengaruh terhadap keputusan pembelian kartu simpati. Dari hasil uji analisis yang telah dilakukan, pada uji secara simultan menjawab bahwa iklan dan citra merek secara simultan berpengaruh positif dan signifikan terhadap keputusan pembelian dengan nilai uji serentak $F_{\text {hitung }}>F_{\text {tabel }}$ dengan nilai $21,110>2.311$.

Lalu pada uji secara parsial, dua variabel dalam penelitian ini secara parsial samasama mempengaruhi keputusan pembelian. Hasil pengujian secara umum menunjukkan bahwa dari 2 variabel Iklan dan Citra Merek, keduanya mempunyai pengaruh secara signifikan terhadap keputusan pembelian kartusimpati di kota Jambi. Pada variabel iklan berpengaruh secara positif dan signifikan dikarenakan nilai uji parsialnya nilai $t_{\text {hitung }}$ sebesar $2.414, t_{\text {tabel }} 1.98$ dimana ini berarti $t_{\text {hitung }}>t_{\text {tabel }}$. Dari penelitian ini dilihat bahwa variabel citra merek berpengaruh secara parsial terhadap keputusan pembelian, dengan nilai uji $t_{\text {hitung }}>t_{\text {tabel }}=4.243>1.98$.

Pada dasarnya setiap perusahaan mempunyai suatu program khusus yang dimana dalam menawarkan setiap produknya perlu menggunakan strategi yang nantinya dapat menarik minat para konsumen atau pelanggan. Salah satunya adalah Telkomsel, dimana perusahaan ini dalam membangun hubungan yang baik perlu didasarkan pada bentuk 
pelayanan yang berkesinambungan dan tidak terisolasi pada satu transaksi tertentu yang nantinya terjalin hubungan baik dari sisi pelanggan maupun dari sisi perusahaan itu sendiri.

Hasil pengujian secara berganda variabel Iklan dan Citra Merek menunjukkan bahwa secara bersama-sama memberikan pengaruh signifikan terhadap variabel $Y$ yaitu keputusan pembelian. Hal ini didukung oleh penelitian yang dilakukan oleh Alfian (2012), $\mathrm{h}$ asil penelitian menunjukkan bahwa sebagian besar keputusan pembelian dipengaruhi oleh citra merek, sedangkan sisanya dipengaruhi oleh faktor lain yang tidak diteliti oleh Alfian. Penelitian lain yaitu oleh Tri Hutomo Putra, Dahmiri. (2018), yang menyimpulkan bahwa keputusan pembeian dipengaruhi oleh Iklan dan promosi penjualan.

\section{KESIMPULAN}

Berdasarkan hasil penelitian dan pembahasan pengaruh iklan dan citra merek terhadap keputusan pembelian kartu simpati di kota Jambi, maka dapat disimpulkan bahwa iklan dan citra merek berpengaruh positif dan signifikan terhadap keputusan pembelian kartu simpati di kota Jambi, Kesimpulan dalam penelitian ini adalah Secara bersama iklan dan citra merek mempengaruhi keputusan pembelian kartu Simpati oleh konsumen di kota Jambi.

Variable iklan secara parsial berpengaruh terhadap keputusan pembelian kartu Simpati oleh konsumen di kota Jambi. Variable citra merek seara parsial berpengaruh terhadap keputusan pembelian kartu Simpati oleh konsumen di kota Jambi.

\section{DAFTAR PUSTAKA}

Alfian (2012). Pengaruh Citra Merek Terhadap Pengambilan Keputusan Pembelian mobil Toyota Kijang Innova Pada PT Hadji Kalla Cabang Polman, Skripsi. Universitas Hasanuddin.

Assael. 1992, Consumer Behvavior. Edisi 1, Bahasa Indonesia New Jersey: Prentice Hall Inc

Baker, Art And Jerry Lezzano.2000. The Windows Device Driver BOOK, A Guide For Rogrammers, Second Edition, Pretrece Hall

Belk, R. 1974. An Exloratory Assessement Of Situastional Effect In Buyer Behavior. Journal Of Marketing Research. May: 156-163

Beaver, H Willim, And Eilen E. Engel.1996. Diserectionary Behavior With To Allowances For Loan Losess And The Behavior Of Security Prices. Journal Of Accounting And Economics. Volume 22

Chaman, Joe And Russ Whalers, 1999, A Rvision And Empirical Test Of The Extended Price-Perceived Quality Model, Journal Of Marketing. P. 53-64

Gempur, Santoso. 2005. Metodologi Penelitian Kualitatif Dan Kuantitatif. Jakarta: Gramedia

Kotler, Philip and Gerry Armstrong. 2012. Prinsip-Prinsip Pemasaran. Edisi 13. Jilid 1. Jakarta: Erlangga .

Kotler, Philip, 2002. Manajemen Pemasaran, Jilid 1, Edisi Millennium, Jakarta: Prehallindo.

Kotler, Philip. 2000. Manajemen Pemasaran, Jilid 1, Edisi Millennium, Jakarta: Prehallindo.

Kotler, Philip. 2005. Manajemen Pemasaran, Jilid 1, Edisi 11, Jakarta: Prehallindo.

Kotler, Philip dan Gary Armstrong, 2003, Dasar-Dasar Manajemen Pemasaran, Jilid 1. Edisi 9. Jakarta: PT Indeks Gramedia.

Kotler, Philip dan Gary Armstrong, 2007, Dasar-Dasar Manajemen Pemasaran, Jilid 1, Alih Bahasa Benyamin Molan. Edisi 12. Jakarta: PT Indeks Gramedia 
Kotler, Philip. 1997. Manajemen Pemasaran: Analisis Pemasaran, Implementasi, Dan Control, jilid 1 (Edisi Bahasa Indonesia Dari Rinciples Of Marketing) Jakarta: Penerbit PT Prehallindo.

Kustandi Suhandang. 2005. Periklanan Manajemen, Kiat Dan Strategi. Bandung, Nuansa Monroe, Kent B. 2005. Pricing: Making Profitabledesicions. New York: mas Milan.

M. Mursid. 2010. Manajemen Pemasaran. Jakarta: PT Bumi Aksara

Mulyani F, (2014), Analisis Pengaruh Iklan, Citra Merek Dan Harga Terhadap Keputusan Pembelian Sampo Sunsilk Di Semarang, Skripsi. Universitas Diponegoro.

Shimp, Terence A, 2003, Periklanan Promosi jilid 1 dan 2, edisi kelima, Erlangga, Jakarta.

Tri Hutomo Putra, Dahmiri. (2018). Pengaruh Iklan Dan Promosi Penjualan Terhadap Keputusan Pembelian Konsumen Pada Produk Smartphone Xiaomi (Studi Kasus Pada masyarakat Kota Jambi terhadap produk smartphone Xiaomi). Jurnal Manajemen Terapan dan Keuangan Vol 7 (2). (127 - 137)

Wahyuni S, (2016), "Pengaruh Iklan, Harga, Dan Kualitas Layanan Terhadap Keputusan Pembelian Kartu Simpati Di Institute Perbanas" JMB No.1 Vol.3

www.telkomselspeedy.com diakses 9 September 2016

www.wikipedia.com diakses Tanggal 9 september 2016. 